\title{
Public attention for private concerns: intellectual disability parents' organisations in the Republic of Ireland, 1955-1970
}

\author{
David Kilgannon
}

Correspondence to Mr David Kilgannon, History, National University of Ireland Galway, Galway H91 CF50, Ireland;

dmkilgannon@gmail.com

Accepted 2 January 2020 Published Online First 14 February 2020
D Check for updates

(c) Author(s) (or their employer(s)) 2020. No commercial re-use. See rights and permissions. Published by BMJ.

To cite: Kilgannon D. Med Humanit

2020;46:483-491

\begin{abstract}
This article examines the influence of intellectual disability 'parents and friends' organisations in the Republic of Ireland between 1955 and 1970, a period that coincided with the emergence of parental disability activism internationally. Drawing on their publications and activities, it argues that Irish groups adopted a significant, if circumscribed, response to 'learning disabilities' that was reflective of a broader political and social policy approach during the midcentury, with local organisations supporting parents of 'deficient' children and establishing key services across the country. It highlights the way in which these pioneering actions align with existing norms in the state and explores the effect of this voluntary-driven response for the intellectually disabled. Approached in this way, the actions of these learning disability organisations complicate international research on postwar disability activism while furthering an emergent body of research into the complex realities that precluded transformative change in Irish society during the mid-20th century.
\end{abstract}

\section{INTRODUCTION}

Dr Cooney was confused. Writing in 1963, the chief medical advisor to the Sisters of Charity religious order seemed bemused by the recent public attention on the 'mentally handicapped' in the Ireland. ${ }^{1}$ This interest had 'never been at such a high level as it is just now', he explained, with increased public discussion being matched by a growing range of services for the disabled. ${ }^{2}$ These developments were not unique to Ireland, as across the world there were numerous changes to the lives of the intellectually disabled, a postwar phenomenon that was termed the 'remaking of mental retardation' in the USA. ${ }^{3}$ Internationally, this transformation included a shift away from the language of eugenics towards a focus on rights, the development of facilities to support 'special education' for the disabled and the introduction of new concepts like deinstitutionalisation and self-advocacy; an evolution that was exemplified by the goals of the United Nations' Declaration on the Rights of Mentally Retarded Persons (1971), which made clear that the person with intellectual disabilities should be supported 'to develop their abilities in various fields of activities ... promoting their integration as far as possible in normal life,. ${ }^{4}$ Within this wide-ranging period of change, parents played an evolving role as they began to form local and national organisations that lobbied on behalf of their 'retarded' children.
The emergence of intellectual disability parents' groups was a trend across the anglophone world, as local organisations developed to provide a fora that offered support and advice for families with a 'handicapped' relative. In the UK, Judy Fryd published an advertisement in the Nursery World magazine to contact other parents of disabled children, an effort that precipitated the formation of the National Association of Parents of Backward Children in $1946 .^{5}$ The formation of regional groups followed a similar pattern in the USA. A 1947 newspaper advertisement preceded the first meeting of the New Jersey Parents' Group for Retarded Children, while the same process helped to form the Association for the Help of Retarded Children in New York City in 1949, regional organisations that coalesced in 1950 to create the National Association of Parents and Friends of Mentally Retarded Children. ${ }^{6}$ In Canada, the first organised group of parents met in Toronto in 1948, a regional group that was incorporated into the Canadian National Parents' Council for Retarded Children in 1951. Meanwhile, parents in New Zealand formed an organisation in 1949, while a public meeting in 1950 instigated the Mentally Retarded Children's Society in Australia. ${ }^{7}$

Multiple explanations have been advanced for the synchronous emergence of these groups during the mid-20th century. In the USA, their development has been presented as both a progressive 'outgrowth of the more general expansion of civic and community organisations as well as a conservative trend that re-enforced a 'stifling set of values: nuclear family, domesticity and togetherness'. ${ }^{8}$ In the UK, their propagation has been linked to both the broader postwar growth in the body of sociopolitical actors and the emergence of 'expert citizens' within public policy debates.' Part of a growing professionalisation across British society, expert citizens drew on specialist experience (cultural capital) to serve as experts within new voluntary organisations and represented the 'bulwarks of an expanding NGO and voluntary sector' that catered for specific groups or interests in this period. ${ }^{10}$ While these explanations vary, a handful of shared features clearly drove the spread of these organisations. Principal among them was a repudiation of eugenics-based thinking in the aftermath of the Second World War (1939-1945). Global awareness of the Nazi involuntary euthanasia programme (Aktion T4), while not decisive in ending eugenics-based policies worldwide, played 
a key role in encouraging parents to discuss the needs of their disabled children in a more public manner. In the wake of these horrors, an American GI explained, parents of the disabled were no longer willing 'to take shit from anybody' when it came to their children. ${ }^{11}$ This candour was augmented by an emergent public discourse on the experience of raising a handicapped offspring, as bestselling memoirs like Pearl S. Buck's The Child Who Never Grew (1950), John Frank's My Son's Story (1952) and Dale Evans Rogers' Angel Unaware (1953) underlined positive features associated with disabled children and legitimated parents' desire to form public organisations. ${ }^{12}$ These memoirs, produced by a Pulitzer Prize winner, a professor of constitutional law and a Hollywood actress, respectively, exhibited how the intellectually disabled were in a range of different and often highachieving families, a variety that implicitly challenged any shame associated with a handicapped relative. Alongside these broader cultural shifts, postwar parental organisations also encountered a particularly supportive environment, as a growing voluntary sector and a buoyant economy encouraged the emergence of specialist associations that were devoted to specialist issues. ${ }^{13}$

In Ireland, the first iteration of this international trend was the Association of Parents and Friends of Mentally Backward Children (hereafter APFMBC), founded in Dublin in 1955. This local group was joined by the National Association for the Mentally Handicapped of Ireland (hereafter NAMHI) in 1961, while a range of regional organisations also emerged across the country, including the Galway Association of Parents and Friends of Mentally Handicapped Children (1962), KARE (Kildare, 1967) and Western Care (Mayo, 1967). Although their propagation aligned with international trends, these groups emerged within a state that had developed a distinctive approach to voluntary services while continuing to lag behind European counterparts both in terms of health services and social security coverage. ${ }^{14}$ The influence of Catholic social teaching, consistent emigration, the dominance of agriculture and the state's neutrality during the Second World War all combined to create a 1950s when Ireland was 'most out of step with Western Europe'. ${ }^{15}$ The reliance on voluntary services also long predates the foundation of the state, with a highly developed network of voluntary services, particularly for 'outlier' groups like unmarried mothers, 'truant' children and the physically disabled, since the late-19th century. ${ }^{16}$ As Carole Holohan has highlighted, this emphasis on voluntary services created a 'variegated and uncoordinated' network of services for the public and often supported a dependence between individuals and the churches in the state. ${ }^{17}$ This cultural climate similarly affected the approach of 'parents and friends' organisations, which had to navigate this denominationally inflected landscape, which presented practical challenges in establishing services and rooted these services in the realm of charity instead of rights.

Drawing on their publications and early activities, this article explores the influence of parents' groups within this cultural environment, using these organisations as a window to explore both approaches to intellectual disability and the broader social services terrain in postwar Ireland. In doing so, it complicates existing research on parental disability activism by showing how groups formed a collective identity and addressed public attitudes to 'learning disabilities', but equally how they struggled to shift the established statutory approach towards necessitous groups like the intellectually disabled. Viewed from this angle, the activities of parents' groups illustrate both the extent of challenges associated with having a mentally handicapped child, as well as charting some of the broader structural barriers that precluded the possibility of transformative change in Irish society during the mid-20th century.

\section{PARENTS AND FRIENDS ORGANISATIONS: PARENTS' MOVEMENT IN IRELAND}

Like its international antecedents, the first Irish disability group emerged from a newspaper advertisement. Prompted by the lack of school facilities for her son Brian, Patricia 'Patsy' Farrell placed a classified advertisement in The Irish Times in June 1955 to contact parents of other 'mentally backward' children. The APFMBC was then formally founded at a meeting in late 1955, which was attended by more than $200 .{ }^{18}$ Established to address issues within South Dublin, the APFMBC was followed by the creation of the national umbrella organisation NAMHI in $1961 .{ }^{19}$ Although extant records are inconsistent, evidence points to the rapid development of both groups. The APFMBC opened their first 'special school' facility in the Dublin suburb of Ranelagh in 1956, where demand remained consistently high for decades, while NAMHI had 91 affiliated organisations across the country by the mid-1970s. ${ }^{20}$ Dominated by parents, alongside some lay professionals engaged in disability services, these organisations (like international counterparts) used those with 'social capital' in the local community to act as figureheads. ${ }^{21}$ During the foundation of a parents association in the west of Ireland, for instance, this included a solicitor, the manager of a local insurance brokerage and a regional journalist. ${ }^{22}$ In the APFMBC, the most prominent figure was the organisation's chairman, Declan Costello, a member of parliament for the centre-right Fine Gael party and the father of an intellectually disabled son. ${ }^{23}$ The role of these prominent public figures was twofold, as they helped in publicising the day-to-day work of these organisations, while the involvement of significant individuals also served to limit the shame associated with an intellectually disabled relative by demonstrating how 'it could happen in any family'. ${ }^{24}$ Parents could be ashamed of a mentally handicapped relative, illustrated by a 1952 account that noted how it was assumed that the disabled person 'would attach a stigma to the family ... [and due to this] In many cases the defective [is] hidden away in the home ... The Mother continues to treat the child as a complete infant, this being the easiest method to adopt'. ${ }^{25}$ By contrast, the association of public figures with a learning disability organisation implicitly challenged this sense of shame and stigma. Similarly, anglophone parents' groups stressed the need for mutual support and the need to secure better services for their children. ${ }^{26}$

This aligned with international trends, with parents' organisations commonly emerging as supportive fora where members could discuss their common challenges. Interviewed in the 1990s, Patsy Farrell described how there was 'great consolation' through this mutual exchange of experiences, as parents began to realise that they were not alone and could begin to talk about their situation in a supportive environment. ${ }^{27}$ Dr Barbara Stokes, the APFMBC's first medical director, accounted for the group's rapid development due to the lack of other support for any 'mentally defective' child (or their parents) in the community. Families were commonly advised to seek an institutional placement, Stokes noted, a process that could conceivably take years, which left the question: what to do in the meantime while the child lived at home? The APFMBC was an attempt to address this question by providing a service that could support parents who were caring for their children in the community while also acting as a didactic forum where members could learn more about parenting a handicapped child. The group held monthly meetings in the Country Women's Club in St. Stephen's Green, where they could share experiences and hear lectures from guest speakers like Carlo Pietzner from the Camphill 'curative' school in Northern Ireland. ${ }^{28}$ 
Through these events, parents helped to limit their isolation by joining together to share stories, advice and information. Lectures that were frequently delivered by prominent international figures in disability gave members an insight into global developments. In March 1961, for example, Dr John Rawlings Rees, director of the World Federation for Mental Health, addressed NAMHI in Dublin. His paper foregrounded the importance of the group's public role in supporting parents and making the disabled visible in society, arguing that they had to operate in as public a manner as possible in order to 'develop a vaccine to inoculate humanity against prejudice'. ${ }^{29}$ Alongside their role in providing support and information, groups also became involved in the direct provision of services. These services were a central goal for groups across the country. Just months after its establishment, the APFMBC began to discuss plans for a special school in South Dublin. This contrasted against Judy Fryd's organisation in the UK, which remained a support group for 5 years before planning their own services. ${ }^{30}$ Patricia Farrell had founded the Dublin group because of her own frustration with the lack of educational facilities available to her son in Westmeath. The speed in Ireland was likely indicative of the narrow range of support available to the midcentury parent, who could avail of little beyond long-term institutional care, a service that was itself grossly oversubscribed and prompted 'handicap' admissions to unsuitable settings like the district psychiatric hospital system. It was therefore understandable that the APFMBC proposed a 'special day school' in early 1956 which could help to educate the 'backward child' and simultaneously offer respite to their family carers during the school day. ${ }^{31}$ Other groups followed the same pattern; KARE in Kildare began as a parents' discussion forum before establishing their special school facility in a local GAA (Gaelic Athletic Association, community) hall. ${ }^{32}$

These efforts reduced the stigma associated with an intellectual disability and brought the mentally handicapped greater visibility in Irish society. This trend was remarked on in a Irish Times editorial on Down syndrome in 1960, which noted the increasingly common sight of the 'devoted and protective mother and her clinging mongol child' in Dublin. ${ }^{33}$ Internationally, research on parents' groups has emphasised their similarities across national boundaries, arguing that they are a broadly similar expression of postwar activism across the 'western' world. ${ }^{34}$ Looking at parents' organisations in Greece, for example, Despo Kritsotaki has argued that the approach adopted by groups across Europe was broadly similar and underlined how disability was becoming 'more than a private concern'. Pointing to how these organisations formed outside of the home, Kritsotaki posited that by forming a group, parents of the disabled entered the public sphere, which meant that families were no longer 'handling a private issue but working for the whole of society' when it came to disability issues. ${ }^{35}$ This transition in thinking surrounding intellectual disability, from a private family concern that was a source of shame to a more public issue, remains important and warrants further exploration across a range of national contexts. In Greece, cultural change supported publicly active parents' organisations, which 'viewed mental retardation as a public issue' by the $1960 \mathrm{~s} .{ }^{36}$ Yet, this process was not so simple in every state. In Ireland, an obviously different narrative emerged, with disability becoming increasingly visible while remaining a private concern for efforts by the voluntary sector. Indeed, in the actions of parents' groups, we can see a response that aligned with an established approach to social services while prioritising the needs of parents over their children.

\section{STATUTORY RESPONSIBILITY?}

St. Michael's House, the state's first special school, was established by the APFMBC in Ranelagh in $1956 .{ }^{37}$ This represented a pivotal moment in the history of disability in the state, yet it was not the first time that a parents' organisation opened a specialist school in the state. Indeed, a range of comparable disabilityspecific voluntary groups were active in midcentury Dublin. The Irish Association for Cerebral Palsy, for instance, opened its first specialist school in 1950. The group's founder, Dr Robert Collis, had repeatedly criticised the department of education for its failure to provide specialist facilities for children with a physical limitation, underlining how it was 'impossible to teach ... [those with cerebral palsy] in ordinary schools. ${ }^{38}$ Similarly, the Central Remedial Clinic, whose early work revolved around the rehabilitation of children with poliomyelitis, opened a school at the organisation's headquarters in Goatstown, South Dublin, in $1956 .^{39}$ The voluntary-driven nature of these specialist school initiatives occurred due to established practices within the department of education, a 'traditionally moribund' wing of government that financially supported schools that were operated by the voluntary sector. ${ }^{40}$

This approach was rooted in 19th century practices, when the Victorian-era state had allowed the development of state-funded denominational primary schools in Ireland. ${ }^{41}$ There was little appetite to assert statutory control over this following political independence in 1922, with successive education ministers closely adhering to the limited role occupied by their predecessors, acting as a conduit for the statutory funding of schools that were owned and operated by the voluntary organisations (usually religious congregations or local churches). ${ }^{42}$ This continued into the mid-1950s, when Minister for Education Richard Mulcahy noted his personal satisfaction with a limited remit as the funder and coordinator of a voluntary education system or, as he liked to put it, the 'plumber who would make the satisfactory connections' to develop new schools. ${ }^{43}$ This limited engagement was despite the adoption of a new constitution in 1937, Bunreacht $\mathrm{Na}$ hÉireann, which placed an obligation on the state to ensure that all children receive a minimum level of education. ${ }^{44}$ This dynamic, where provision was 'left to voluntary societies and the range of their activities', presented an obvious challenge for families with a handicapped child. ${ }^{45}$

In line with European trends, Irish social policy increasingly oriented itself towards greater intervention in the lives of citizens throughout the midcentury. ${ }^{46}$ This process was exemplified by the formation of a separate department of health in 1947 , an administrative reform that was followed by a flurry of new proposals, with officials in the new department attempting to expand access to services and address long-standing deficiencies. ${ }^{47}$ This marked the beginning of a new legislative approach to public health issues, with the 1947 Health Act and the white paper Outline of Proposals for the Improvement of the Health Services appearing to mark the start of a journey towards a public health system comparable to the British NHS. ${ }^{48}$ Yet, expansion did not occur along these lines; Sarah-Anne Buckley has noted how the state instead perpetuated an established reliance on voluntary health services, which limited the need to develop statutory alternatives. This meant that, instead of a statutory health system, voluntary provision expanded alongside the state. ${ }^{49}$

Ruth Barrington has argued that Irish opposition to growing state intervention in the mid-20th century arose from indigenous interest in applying papal teachings to contemporary social issues. ${ }^{50}$ Central to this process were the twin concepts of 'subsidiarity' and 'familialism'. First articulated in Pope Pius 
XI's encyclical, Quadragesimo Anno (1931), subsidiarity had a notable impact on midcentury social thinking. ${ }^{51}$ Produced during the rise of totalitarian regimes across Europe, Quadragesimo Anno sought to describe the correct ordering of society under a Catholic paradigm, arguing that the state should refrain from providing direct support but could facilitate smaller (subsidiary) organisations like voluntary organisations or families to carry out tasks on the state's behalf. In the 1956 textbook A Manual of Social Ethics (1956), the priest, lecturer and later auxiliary bishop of Dublin, Dr James Kavanagh, described how, under a subsidiarist framework, the Irish state should remain slow to increase its social services. The voluntary sector was key, as the organs of the state 'should not supplant them when they can partly do things but should supplement their efforts' ${ }^{52}$ This aligned with the original papal encyclical, which affirmed how 'it is an injustice and at the same time a grave evil and disturbance of right order to assign to a greater and higher association what lesser and subordinate organisations can do. ${ }^{53}$ Applying subsidiarity within public policy meant consistently favouring smaller voluntary provision over wider statutory services, with state intervention 'regarded as merely a first-aid measure'. ${ }^{54}$ This approach was particularly visible in legislative measures like Section 65 of the 1953 Health Act, which allowed the department of health to financially support voluntary organisations to provide services on their behalf, while the department of education maintained a subsidiarist approach in their development of schools through religious congregations or local churches rather than the state. ${ }^{55}$

This idea was closely linked to the concept of familialism, which prioritised the family and framed its support as an imperative for the effective functioning of the wider state. ${ }^{56} \mathrm{Mel}$ Cousins has argued that familialism played an implicit role across all discussions on welfare expansion during the mid-20th century and that it served to limit the state's role. This ideology, he argued, viewed that

By natural and divine law, the father of the family was bound to maintain his home for himself, his wife and his family. The state should not attempt to relieve him of this duty and privilege, but should assist him so that he could better meet these obligations. ${ }^{57}$

As others have noted, subsidiarity and familialism are both general ideas and do not offer an explicit framework for how the state should function on a granular level, only the general goals that it should aspire towards. Indeed, this ambiguity is inherent to Quadragesimo Anno, which 'carefully avoids details and specific applications' for its ideas. ${ }^{58}$ Building on this, Tony Fahey has suggested that the idea of Catholic-based ideological resistance to welfare expansion has been overblown by historians, noting how the hierarchy's concern was much more 'intermittent and unsystematic than is often believed, ${ }^{59}$

$\mathrm{He}$ is undoubtedly correct, in that the church's position evolved across the mid-20th century, so that by the early 1960s, it 'was more likely to demand rather than decry state intervention' on issues relating to welfare and poverty. ${ }^{60}$ Yet, the maintenance of a subsidiarist framework had obvious advantages for the state as it allowed them to financially support a voluntary organisation to provide services on their behalf. Provided under a 'grant in aid' rather than a contractual framework, 'Section 65 ' grants were obviously preferable to a statutory alternative for the midcentury bureaucrat. First, these grants necessitated that any services were not totally funded by the state, meaning that a proportion of overall funding had to be raised privately, either through fundraising or contributions, thereby reducing a project's cost. ${ }^{61}$ These grants also negated any statutory liability or obligations. Services, while they may receive the majority of their funding from the state, remained private charitable initiatives that were supported by the state rather than what they were: de facto statutory services. ${ }^{62}$ Given this, there was no obligation for statutory inspections, as were required for state-run institutions like psychiatric hospitals, while it also meant that there was no obligation to ensure parity of provision in the availability of services across the country. For contemporary politicians and civil servants, operating in a period when religious congregants were plentiful and the church already played a key role in health and welfare services, the advantages of such an approach were obvious. Through recourse to subsidiarity, services could be provided cheaper, without the impediments attached to state provision, and any potential deficiencies could be framed as a failure by these individual voluntary sector groups. On top of these manifold advantages, this approach also allowed the contemporary politician to argue that they were showing due regard to the correct operation of a Catholic state, which was supposed to afford an expansive autonomy to both the family and the voluntary sector. This approach was formally endorsed by the 1960 white paper 'The Problem of the Mentally Handicapped', which noted how $£ 1.6$ million in hospital trust grants had been paid to religious orders for expansions to their institutional services. The white paper also commended similar voluntary efforts across the country, such as a boarding school in Cork and a Waterford day care centre, and called for further grants to support these voluntary endeavours. ${ }^{63}$

This charity-based approach shaped the discussion of intellectual disability within public fora, like the Irish parliament (Dáil Éireann), where Deputies noted the need to support these services, not as a matter of rights or public responsibility but as an example of the state's Christian character. Fine Gael's Timothy Manley was typical when he described the work of the Brothers of Charity at the Our Female of Good Counsel centre in Lota, Cork, as a living exemplar of Christian virtue and detailed how it was a 'revelation to go into these institutions and see the spirit of devotion, self-sacrifice and loyalty which the brothers display towards the children'. ${ }^{64}$ The framing of this was telling, in that politicians discussed these services in terms of statutory beneficence, not responsibility. By contrast, in the UK Judy Fryd explicitly spoke about this issue in terms of the state, describing how British parents should feel unafraid to demand statutory action as it was 'what they pay rates and taxes for - namely, education suitable for their special needs in schools specially built for the purpose'. ${ }^{65}$

\section{PARENTAL ORGANISATIONS}

This cultural context shaped the response from parents' organisations across the country, who came to occupy a central role in the provision of supports for parents and services for the intellectually disabled. Mary Daly had noted the scale of efforts by figures like John Charles McQuaid, the Catholic Archbishop of Dublin, to ensure the training of religious congregations to assess and educate the disabled. ${ }^{66}$ Yet, the recipients of this training were commonly directed to roles within schools that were attached to existing religious-operated residential facilities, such as the special school operated by the Brothers of Charity beside their centre at Lota, Cork. Given the absence of alternatives, there was an obvious burden on voluntary disability organisations to establish their own educational services, a responsibility that they came to regard as part of their broad role. Dan O'Donovan, one of the founders of the Kildare-based organisation KARE, described in a 1977 newsletter how parents with a disabled child 
always had a dual remit, as they had to dispel stigma and develop better services for everyone with a disability: 'The child was born handicapped and now it is your job and mine to get on and do something about it'. ${ }^{67}$ This sense, that if parents did not act to establish appropriate services no one else would, prompted the foundation of 13 'special schools' in the community by $1965 .{ }^{68}$ Mary Daly has noted how Irish parents were denied a formal role in the education system throughout the mid-20th century. ${ }^{69}$ Yet, this did not prevent parents from acting when their specialist needs were neglected by both the church and the state, both of whom failed to act to provide specialist educational facilities for the mentally handicapped child.

Indeed, this proactive approach by parents' groups persisted and expanded over time, with the remit of voluntary organisations growing beyond a focus on services for the disabled child to include adult services, driven by the fact that the state would not provide funding for school attendance by any person over the age of 18 years regardless of their level of need. ${ }^{70}$ Faced with this, groups established facilities to address adults with disabilities who were 'ageing out' of the school system, which included both community-based housing and occupational training facilities. At the APFMBC's St. Michael's House in Dublin, for instance, they established an occupational workshop for those over 18 years, where former pupils were involved in "collating printed material ... packing and carding "handy-packs" - "lucky bags' [and] assembling simple components for [the] electrical trade. ${ }^{71}$

While these parents' organisations were successful in integrating some international ideas (like normalisation) into these services, ideas like self-advocacy had a limited impact. This concept, which held that the intellectually disabled were empowered individuals with agency who should be supported to make their own decisions, remained notably absent into the 1990s. Indeed, groups continued to discuss their 'children' within organisational documents, an understanding that infantilised disabled adults and preserved ideas about the innocence associated with an intellectually disabled person. ${ }^{72}$ Indicative of this, groups commonly pointed to the Gaelic term for a disabled person, duine le dia or person of God, as evidence of the innocence associated with the mentally handicapped. ${ }^{73}$ The implications of this went beyond semantics in that it maintained services in the realm of charity, meaning that the intellectually disabled-alongside victims of a humanitarian disaster or abandoned pets-were worthy because of their blameless nature. These 'people of god' were entitled to services due to their nature, not through recourse to their constitutional rights as citizens. This influenced the way groups developed services, prompting an overwhelming emphasis on public fundraising initiatives by local groups. The parents and friends organisation at the Saint Augustine's Institute in Blackrock, for instance, were involved in the construction of a series of chalets on the grounds of the main institution. Rather than asking the state to pay for this accommodation, the group raised the funds for this project. Dun Laoghaire Soroptimist Club furnished one of the houses, while the nearby confectionery manufacturer Rowntree-Mackintosh donated a minibus for the complex. ${ }^{74}$ They also carried out a sizeable fundraising campaign to equip a playground, an initiative that was also supported by a local youth club. ${ }^{75}$ This ad hoc approach, which meant developing an individual service to address an existing need, remained in place. Rather than calling for systemic reform, or widespread statutory engagement, groups continued to provide services wherever they could in this fashion, an approach that fundamentally shaped the nature of 'handicap services'.
The conception of the disabled as 'eternal children' among parents' groups also shaped their identity, as they commonly viewed parents as the pivotal figure in changing public perceptions around intellectual disability. They were clearly groups for the intellectually disabled, not representative of them. Johnny Mee, from the rural Western Care organisation, explained how his group was being innovative in foregrounding parents, when openly talking about a child's disability 'was something that never had been tried or never been achieved in Mayo. It was almost like putting the first man on the moon ${ }^{76}$ In their efforts, organisations viewed themselves as the pivotal interlocutors between the disabled person and the wider Irish society. Given this, their perception of disability remained important, as this shaped their activities. Commonly, groups acknowledged the biological aetiology of disability and sought the help of medical professionals in shaping their discussion, as when NAMHI's booklets were produced by Dr Noreen Buckley. Disability was, to an extent, viewed as an immutable biological category, as parents were encouraged to accept their 'child's limited capabilities' and, from the mid-1960s, there is some discussion of the genetic basis of conditions like Down syndrome. ${ }^{77}$ Nonetheless, groups also noted the importance of wider society in supporting the intellectually disabled to best develop their abilities, thus moving closer to the social model of disability, which foregrounded the need for services that helped the disabled to function effectively in wider society and emphasised the societal dimensions of an individual's cognitive limitations. ${ }^{78}$

When it came to the intellectually disabled, reliance on this voluntary-driven approach meant that provision emerged slowly, often requiring years of 'flag days' and fundraising efforts before being able to establish any facility. When a group (eventually) received their statutory funding, it was via Section 65 grants through the department of health or the partial funding offered by education, both of which discouraged any further innovation, out of fear that this precarious funding could disappear in the following year. Section 65 payments remain an opaque process into the 21 st century, with little visible rationale for their varying payment rates or diverging practices nationwide. ${ }^{79}$ Inevitably, this funding structure influenced the approach adopted by voluntary organisations, with these (seemingly arbitrary) grants discouraging both criticism of the state and innovation in their actions. Groups were understandably hesitant to highlight any statutory deficiencies, while the department's opaque approach also discouraged groups from changing their practices or reforming ailing services. Tom Fallon, again from Western Care, described the precarious nature of the organisation into the 1980s due to this funding structure, where 'We always had financial fears, all along the line ... there were months when the money wasn't in the kitty to pay my wages' ${ }^{80}$ Reliance on parents' groups to manifest services also meant that disability provision frequently represented the goals of an organisation's committee, rather than their service users, producing facilities that were a respite for home carers through a limited education in special schools or diversionary 'training' in an occupational workshop. The state could not know this, however, as its lack of statutory oversight meant that it financially supported services that were supposed to advance specific policy goals (around integration and normalisation), but could never ensure that provision was actually matching up to these new standards. This meant that voluntary organisations had the autonomy to develop their own programmes and could draw from existing models established elsewhere, but there was equally no oversight of the nature of these services or any efforts to ensure their consistent availability across the country. In practice, this structure meant 
that parents' organisations adopted a broadly similar approach across the country, establishing the services they considered to be necessary, with varying results, like when St. Gabriel's School in Limerick provided 'classes' that were taught by nurses instead of teachers. ${ }^{81}$

\section{CONCLUSION}

A NAMHI booklet from the mid-1960s encouraged parents to bring their handicapped child into wider society as soon as possible, explaining that

All children need fresh air, so get your baby out frequently, take him to the shops with you, this gives you an easy way to introduce him and show him to friends and neighbours. Perhaps this is something you have been putting off or dreading, don't worry. 1/16 of families have a handicapped relative somewhere along the line, people are kind, sympathetic and interested, give them a chance to show their interest. ${ }^{82}$

Writing in the mid-1980s, Anne Borsay proposed a dual vision of disability, as either a personal trouble or a social issue. ${ }^{83}$ Through their actions, it is clear that parents' organisations in midcentury Ireland sought to broaden the issue of disability from a private family-specific concern to something that included broader society in the 'problem of the mentally handicapped' ${ }^{84}$ By rejecting previous associations of disability with eugenics and family stigma, the parents' movement was innovative in expanding learning disability issues into a wider concern, something that the state had some responsibility in supporting. Diarmaid Ferriter and Lindsey Earner-Byrne have both noted how the postwar period witnessed a similar broadening of the state's remit in health issues, with a new focus on preventative medicine within legislation like the 1947 Health Act. ${ }^{85}$ Yet, this growth of the state's role did not directly encompass cases of intellectual disability, as support for voluntary disability organisations was regarded as evidence of the state's moral character, not the fulfilment of its responsibility. This approach, which emphasised voluntary services and limited statutory engagement, was intimately linked to the broader cultural background that underlay Irish social policy during the 1950s.

The actions of parents and friends organisations highlight how the international remaking of mental retardation emerged in the Irish state, a trend that produced a more public approach towards the intellectually disabled across Irish society, while new services for this group developed within the confines of a conservative social services landscape that prioritised voluntary provision. In their efforts, parents' groups sought public attention for their children and highlighted the worthiness of supporting the disabled as a cause, but ultimately could not elevate the issue to that of a public concern for the state. These groups have considerable autonomy to shape the nature of their services, but ultimately left these individual organisations as the dominant provider of learning disability facilities into the 21st century. Exploring this dynamic offers considerations for both the history of disability in Ireland and the broader history of 'mental retardation' beyond the state.

In a national context, the parents' organisations established a range of services for the intellectually disabled, as voluntary organisations opened special schools, community-based residences and occupational training facilities across the country, often providing the only available services in an area. They were also influential in shifting public attitudes towards the disabled. By bringing parents together into a collective organisation, groups like the APFMBC helped to gradually dispel earlier stigmas associated with a disability and highlighted the need for better services to support children to function in wider society. Attending meetings gave parents an opportunity to discuss the challenges of raising an intellectually disabled child in a supportive environment, thus reducing the isolation of family carers, while these gatherings also exposed parents to international research concerning the best approaches to health and education for the mentally handicapped. Over time, these organisations included disabled adults in their remit, as efforts to establish schools expanded to include initiatives to open work training programmes. The sense that there had been progress in the lives of the disabled in Ireland, that 'what is certain is that it is better to be born handicapped today than it would have been a hundred, or even thirty years ago', rested on the work of these organisations, which developed services and foregrounded the needs of the disabled in a fundamentally new and obviously public-facing manner. ${ }^{86}$

Yet, the very prominence of their efforts reflects the structural barriers that precluded broader change in midcentury Ireland. The new approach to disability services was introduced into a state that had a distinct historical legacy of charitable services and where the multiplicity of voluntary providers created an obstacle for more coherent reform. In this way, the mentally handicapped provide a specific example of Mary Daly's argument that the 'long 1960s' (1957-1973) in Ireland was a period when necessary changes were 'moderated in such a manner that many of the core institutions survived and even thrived' ${ }^{87}$ Daly argued that this impulse to moderate change was not conscious but instead represented an attempt to placate the varied stakeholders in Irish society and to broadly maintain the status quo. This aligns with the experiences of the disabled, where the international impulse of postwar parental advocacy was reshaped to fit with the historic dominance of the voluntary sector. Parents' groups highlighted the paucity of existing services for the disabled. Yet, without being able to address the broader relationship between the state and the voluntary sector, groups were left with little option other than developing their own ad hoc services before being incorporated into a restrictive funding relationship with the state.

While existing research has highlighted the similarities in parents' organisations internationally, this article has instead highlighted the importance of national context in shaping the approach to disability in Ireland, thereby complicating Kritsotaki's 'public concern' argument. ${ }^{88}$ Indeed, despite being in receipt of public funds and operating openly in the community, voluntary sector provision remained akin to a private enterprise, with no entitlement to a service, parity of provision or oversight. The funding structures of the 1953 Health Act supported these voluntary initiatives while keeping them at a distance from the broader work of the state. This clearly complicates the idea that all parents' organisations foregrounded disability as a public problem; as in the Irish case, the handicapped were increasingly visible, while this did not ascend to the foreground of social concerns during the mid-20th century. This reliance on the voluntary sector went on to have a long-standing impact on the shape of disability services in the state, seen in the fact that Ireland was the last in Europe to ratify the United Nations' Convention on the Rights of Persons with Disabilities in 2018, a lethargy that was attributed to the range of statutory obligations associated with the convention. ${ }^{89}$ Although seemingly insignificant, the congregation of parents into these local disability organisations proved critical to the development of community-based services for the mentally handicapped, while their approach reflects the state's broader social services infrastructure and its approach 
to vulnerable groups. In doing so, it not only contributes to an emerging understanding of 1960s Ireland as a period of tempered change but also highlights the need for greater research on the distinctive national character of postwar disability organisations.

Twitter David Kilgannon @david_kilgannon

Funding This study was funded by Wellcome Trust (grant number 108597/Z/15/Z).

Competing interests None declared.

Patient consent for publication Not required.

Provenance and peer review Not commissioned; externally peer reviewed.

Data availability statement There are no data in this work. No data are available. Not Applicable.

\section{NOTES}

1. This research uses 'intellectual disability' to denote a broad group of conditions that were associated historically with forms of cognitive or functional impairment. This term was used in light of its prevalence in Ireland, while 'learning disability' and 'developmental disability' remain the dominant nomenclature in the UK and the USA, respectively. This work also engages with language that remains clearly offensive, including 'mentally deficient', 'feeble-minded', 'mentally subnormal' and 'retarded'. The use of these terms is not intended to offend the reader or to condone the limited conception of the individual that is conveyed through their use. They are instead presented to accurately discuss the linguistic discourse that surrounded intellectual disability in this period, which in itself grants an insight into how 'mentally handicapped' individuals were understood during the mid-20th century.

2. John Cooney (1963), A Service for the Mentally Handicapped (Dublin, 1963), p. 1, Royal College of Physicians of Ireland Archive, CSFH/1/4/4.

3. James Trent (1994), Inventing the Feeble Mind: A history of Mental Retardation in the United States (Berkeley, 1994), pp. 225-68; While Trent's term is confined to the USA, the broader trends that he describes are also discussed in Allison C. Carey, On the margins of citizenship: intellectual disability and civil rights in twentieth century America (Philadelphia, 2009), pp. 84-9; Sheena Rolph (2002), Reclaiming the past: the role of local MENCAP societies in the development of community care in East Anglia, 1946-80 (Milton Keynes, 2002), pp. 6-8; Anne Borsay (2004), Disability and Social Policy in Britain since 1750: A History of Exclusion (Hampshire, 2004), pp. 1-17.

4. United Nations (1984), 'Declaration on the Rights of Mentally Retarded Persons' (1971) in American Psychiatric Association (ed.) Rights of the Mentally Disabled: Statements and Standards (Washington, 1984), p. 8.

5. Matthew Hilton et al. (2012), A historical guide to NGOs in Britain: Charities, Civil Society and the Voluntary Sector since 1945 (Hampshire, 2012), p. 50.

6. Kim Nielsen (2012), A Disability History of the United States (Boston, 2012), p. 142; Katherine Castle (2004), '"Nice, average Americans": post-war parents' groups and the defence of the normal family' in Mental Retardation in America: A historical reader (New York, 2004), p. 351; Fred Pelka (2012), What We Have Done: An Oral History of the Disability Rights Movement (Amherst, 2012), p. 131.

7. Rose Blackmore, 'Developmental Challenges' in Francis J. Turner (ed.) Encyclopedia of Canadian Social Work (Ontario, 2009), p. 101; The Australian group later became known as Orana. Ian Lewis (2010), Making a difference: sixty years of service to the people of South Australia, 1950-2010 (Netley, 2010), p. 5; David Wright (2011), Downs: The history of a disability (Oxford, 2011), p. 148.

8. Katherine Castle (2004), '“Nice, average Americas"', p. 353; Kathleen W Jones (2004), 'Education for children with mental retardation: Parent Activism, Public Policy and Family Ideology in the 1950s' in Mental Retardation in America: A historical reader (New York, 2004), p. 341.

9. Matthew Hilton et al. (2012), A Historical Guide to NGOs in Britain, p. 23; Matthew Hilton et al. (2010), 'The Big Society: Civic Participation and the state in Modern Britain' History and Policy, June 2010, p. 7.

10. Harold Perkin (2003), The Rise of Professional Society: England Since 1880 (Abingdon, 2003), p. 418; Henrik P Bang (2005), 'Among everyday makers and expert citizens' in Janet Newman (ed.) Remaking Governance (Bristol, 2005), p. 160; Matthew Hilton, James McKay, and Jean-François Mouhot (2013), The Politics of Expertise: How NGOs Shaped Modern Britain (Oxford, 2013), p. 10; Pierre Bourdieu (1986), 'The Forms of Capital', pp. 241-58.

11. David Wright (2011), Downs, p. 107; Allison C Carey (2009), On the Margins, p. 108; Tim Stainton (2000), 'Equal Citizens? The discourse of liberty and rights in the history of learning disabilities' in Lindsay Brigham \& Dorothy Atkinson (et al.) Crossing Boundaries: Change and Continuity in the History of Learning Disability (Kidderminster, 2000), pp. $87-101$.
12. Pamela Abbott and Roger Sapsford (1988), Community Care for Mentally Handicapped Children (Milton Keynes, 1988),p. 48; Pearl S Buck (1950), The Child Who Never Grew: A Memoir (New York, 2012 [1950], p. 2.

13. Matthew Hilton et al. (2012), A Historical Guide to NGOs in Britain, p. 23.

14. Maev-Ann Wren (2002), Unhealthy State: Anatomy of a sick society (Dublin, 2002), pp. 124-6; Mel Cousins (2016), 'The Irish Social Protection System: Change in a Comparative Perspective' in Mary P. Murphy \& Fiona Dukelow (eds.) The Irish Welfare State in the Twenty-First Century: Challenges and Change (London, 2016), pp. 38-41.

15. Mary Daly (2016), Sixties Ireland: Reshaping the Economy, State and Society, 1957-73 (Cambridge, 2016), p. 2.

16. See - Eoin O'Sullivan (1999), Suffer the Little Children: The inside story of Ireland's Industrial Schools (Dublin, 1999); Frances Finnegan (2004), Do Penance or Perish: Magdalene Asylums in Ireland (Oxford, 2004); Annie Ryan (1999), Walls of Silence: Ireland's policy towards people with an intellectual disability (Kilkenny, 1999).

17. Carole Holohan (2016), 'Conceptualizing and responding to poverty in the Republic of Ireland in the 1960s: a case study of Dublin' Social History 41(1, 2016), p. 38.

18. Mary Daly (2009), "The primary and natural educator'?: The role of parents in the education of their children in Independent Ireland' Éire-Ireland 44 (1\&2) Spring/ Summer 2009, p. 212; Commission on Mental, p. 11; 'Association to aid backward children' Irish Press, 11 November 1955, p. 7.

19. Andrew Power (2010), Landscapes of Care: Comparative Perspectives on Family Caregiving (Abingdon, 2010), p. 133.

20. Notes for Parents: Number Three (Dublin, 1976), National Library of Ireland (hereafter NLI) Ir 6168 p4; The Association of Parents \& Friends of Handicapped Children, St Michael's House Annual Report: 1975 (Dublin, 1976), p. 1.

21. Pierre Bourdieu (1986), 'The Forms of Capital' in John G. Richardson (ed) Handbook of Theory and Research for the Sociology of Education (Westport, 1986), pp. 241-58.

22. 'To help Mentally Defective Children' Cork Examiner, 24 May 1958, p. 6; 'Mentally III children' Irish Independent, 17 July 1958, p. 9

23. Pierre Bourdieu (1986), 'The Forms of Capital', pp. 241-58; Ciara Meehan (2013), A Just Society for Ireland? 1964-1987 (Hampshire, 2013), p. 46.

24. Josephine (Josie) McGowan, Oral History Interview, 5 September 2017.

25. B. Kelly, 'A social problem' in Loreto Annual 1951 (Dublin, 1951), p. 58.

26. James Trent (1994), Inventing, pp. 225-68; Allison C Carey (2009), On the margins, pp. 84-9; Sheena Rolph (2002), Reclaiming the past, pp. 6-8; Rubahanna Amannah Choudhury (2015), 'The Forgotten Children: The Association of Parents of Backward Children and the Legacy of Eugenics in Britain, 1946 - 1960' (PhD Thesis, Oxford Brookes University, 2015), p. 259

27. Patricia Farrell, 'Personal' The Irish Times, 2 June 1955, p. 10; Annie Ryan (1999), Walls, p. 75; 'Welfare of Mentally Retarded Children' Cork Examiner, 19 October 1957, p. 6; Sheena Rolph, Reclaiming, p. 2.

28. 'To aid handicapped children' Irish Press, 26 November 1955, p. 2.

29. 'Association helps handicapped children' The Irish Times, 3 March 1961, p. 9.

30. Rubahanna Amannah Choudhury (2015), 'The Forgotten Children', p. 259.

31. Commission on Mental, p. 11; Bernard Farber (1968), Mental Retardation: Its social context and social consequences (Boston, 1968), p. 147.

32. Vicki Weller (1992), An Extraordinary Voluntary Commitment: 25 Years of KARE (Kildare, 1992), pp. 9-11.

33. Dr. Alfred Byrne, 'Chromosome and the Mongol' The Irish Times, 16 August 1960, p. 6. 34. See - David Wright (2011), Downs, pp. 145-50.

35. Despo Kritsotaki (2016), 'Turning Private Concerns', p. 988.

36. Ibid, p. 992

37. Mary Daly (2009), 'The primary', p. 212.

38. Robert Collis, 'Letters to the Editor: Cerebral Palsy' The Irish Times, 7th January 1950, p. 8.

39. Valerie Goulding, 'Fundraising Appeal: The Central Remedial Clinic', Dublin Diocesan Archive, Central Remedial Clinic Papers, L9/3.

40. Joseph Lee (1989), Ireland, p. 361; Donald Akenson (2012), A Mirror to Kathleen's Face: Education in Independent Ireland 1922-60 (Abingdon, 2012), p. 117.

41. Antonia McManus (2004), The Irish Hedge School and Its Books, 1695-1831 (Dublin, 2004), pp. 1-3; Donald Akenson (2012b), The Irish Education Experiment: The National System of Education in the Nineteenth Century (Abingdon, 2012), p. 46

42. John Coolahan (1981), Irish Education, p. 185; Michael Shevlin, 'Historical Development', pp. 183-7; John Henry Whyte (1980), Church and State, p. 337.

43. Tom Inglis (1998), Moral monopoly : the rise and fall of the Catholic Church in modern Ireland (Dublin, 1998), p. 57; Sean Healy and Brigid Reynolds (2006), Social Policy in Ireland: Principles, Practice and Problems (Dublin, 1989), pp. 383-5; Patrick Clancy (1995), 'Education in the Republic of Ireland: the project of modernity?' in Patrick Clancy (ed.) Irish Society: Sociological Perspectives (Dublin, 1995), p. 474.

44. Article Forty-One, Bunreacht Na hÉireann (Dublin, 2012), p. 166. 
45. John Coolahan (1981), Irish Education, p. 185.

46. Geoffrey Finlayson qtd. in Martin Gorsky, 'Voluntarism in English Health and Welfare' in Donnacha Sean Lucey \& Virginia Crossman (eds.) Healthcare in Ireland and Britain: 1850-1970 (London, 2015), p. 57; Roger Cooter (2011), 'Medicine and Modernity' in Mark Jackson (ed.) The Oxford Handbook of the History of Medicine (Oxford, 2011), pp. 100-17; John Pickstone (2001), 'Medicine, society and the state' in Roy Porter (ed.) The Cambridge Illustrated History of Medicine (Cambridge, 2001), pp. 304-8.

47. Ruth Barrington (1987), Health, pp. 248-9.

48. Lindsey Earner-Byrne (2007), Mother, p. 126; Ruth Barrington (1987), Health, p. 188. 49. Sarah-Anne Buckley (2013), The Cruelty Man, p. 201; Geoffrey Finlayson (1990), 'A Moving Frontier: Voluntarism and the State in British Social Welfare 1911-1949' Twentieth Century British History 1(2) January 1990, pp. 183-206.

50. Ruth Barrington (1987), Health, Medicine and Politics, pp 143-4.

51. The encyclical title translates literally as 'In the fortieth year' and is regarded as a review of the major societal trends since the publication of Pope Leo XIII's Rerum Novarum in 1891. John Pollard (2016), The Papacy in the age of totalitarianism 1914-58 (Oxford, 2016), p. 244; Ciara Meehan (2013), A just society for Ireland? 1964-87 (Basingstoke, 2013), p. 8; Louise Fuller (2004), Irish Catholicism since 1950: the undoing of a culture (Dublin, 2003), p. 69; Peter Murray and Maria Feeny (2016), Church, State and Social Science in Ireland: Knowledge Institutions and the Rebalancing of Power 1937-73 (Oxford, 2016), p. 18.

52. James Kavanagh (1956), Manual of Social Ethics (Dublin, 1956), p. 54

53. Pope Pius XI, Quadragesimo Anno, 15 May 1931. (http://w2.vatican.va/content/piusxi/ en/encyclicals/documents/hf_p-xi_enc_19310515_quadragesimo-anno.html) (21 February 2018); Andrew Power, Janet E. Lord, and Allison DeFranco (2013), Active Citizenship and Disability: Implementing the Personalisation of Support (Cambridge, 2013), p. 365.

54. Jerome O'Leary, 'Social Topics' Christus Rex VIII(1) January 1954, p. 61.

55. Government of Ireland, Health Act 1953.

56. This idea was directly articulated during a 1964 Dáil debate over succession, in which Fianna Fáil deputy Brian Lenihan argued that the family in Ireland represented 'the moral institution forming the necessary basis of social order'. Brian Lenihan, Dáil Debates 213, 2 December 1964, col. 337.

57. Mel Cousins, The Birth of Social Welfare in Ireland, p. 199.

58. Donal Dorr (1983), Option for the Poor: A Hundred Years of Vatican Social Teaching (New York, 1983), p. 80.

59. Tony Fahey, 'The Catholic Church and Social Policy' in Seán Healy \& Brigid Reynolds (eds.) Social Policy in Ireland. Principles, Practice and Problems (Dublin, 1998), p. 153.

60. Carole Holohan (2016), 'Conceptualising and responding to poverty in the Republic of Ireland in the 1960s: a case study of Dublin' Social History 41(1) 2016, p. 45.

61. Brian Harvey (2007), Evolution of Health Services and Health Policy in Ireland (Dublin, 2007), p. 8.

62. Andrew Power, Janet E. Lord, and Allison DeFranco (2013)., Active Citizenship, p. 354; Andrew Power \& Kate Kenny, 'When care is left to roam', p.424.

63. Department of Health, The Problem of the Mentally Handicapped, p. 6; Commission on Mental Handicap, 1965 Report, p. 32.

64. Timothy Manley, Dáil Debates 167, 29 April 1959, col. 1015.

65. Ibid.

66. Mary Daly, 'The Primary', p. 209.

67. Dan O'Donovan qtd in Vicki Weller, An extraordinary voluntary commitment: 25 years of KARE (Kildare, 1992), p. 30.

68. Department of Education, Statistical Report of the Department of Education 1965-66 (Dublin, 1966), p. 8.

69. Mary Daly (2009), '"The Primary"', p. 215.

70. This controversial policy would later be upheld by the Supreme Court in Sinnott v. Minister for Education (2001), when the court agreed that ending an individual's formal education at 18 did not impinge on their constitutional rights. Sinnott $\mathrm{v}$. Minister for Education (2001) 2 IR 545, 600; Thomas Murray (2016), Contesting Economic and Social Rights in Ireland: Constitution, State and Society, 1848-2016 (Dublin, 2016), p. 262.

71. The Association of Parents and Friends of Handicapped Children, St. Michael's House Annual Report: 1975 (Dublin, 1976), p. 10.

72. Mark Jackson (2003), 'Grown-Up Children': Understandings of Health and Mental Deficiency in Edwardian England' in Marijke Gijswijt-Hofstra \& Hilary Marland (eds.) Cultures of Child Health in Britain and the Netherlands in the Twentieth Century (Amsterdam, 2003), pp. 149-68.

73. Daithí Ó hÓgáin, 'Simpleton' in Donald Haase (ed.) The Greenwood Encyclopedia of Folktales and Fairy Tales: Q-Z (Westport, 2008), p. 867; Tom Shakespeare, 'Disabled people's self-organisation: A new social movement?' in Len Barton (ed.) Overcoming Disabling Barriers: 18 Years of Disability and Society (Abingdon, 2006), pp. 53-70.

74. Mary Purcell, A time for sowing, p. 120.
75. Ibid.

76. Johnny Mee, 'Breaking New Ground' in Liam MacNally (ed.) Western Care: Celebrating Forty Years (Castlebar, 2007), p. 7

77. Noreen Buckley, What can I do to help my child: practical advice on the home care of the Mentally Handicapped (NAMHI Pamphlet, Dublin, 1975), p. 1.

78. Lennard Davis (1997), 'Introduction: The need for Disability Studies' in Lennard Davis (ed.) The Disability Studies Reader: Second Edition (New York, 1997), p. 3; Paul K. Longmore, Why I Burned My Book and Other Essays on Disability (Philadelphia, 2003), p. 20; Dan Goodley, Disability Studies: An Interdisciplinary Introduction (New York, 2016), p. 11; Valerie Leiter, 'Parental activism, professional dominance and early childhood disability' Disability Studies Quarterly 24 (2) 2004; James Trent (1994), Inventing, pp. 225-68; Sheena Rolph (2002), Reclaiming, pp. 6-8.

79. Andrew Power (2010), Landscapes, p. 130, p. 136; Brian Harvey, Evolution, p. 7.

80. Tom Fallon, 'Talk about small beginnings!' in MacNally, Western Care, p. 15.

81. David Loughnane, 'The Provision of Disability Services in Limerick 1930-1990' (M.A. Thesis, Mary Immaculate College, 2013), p. 80.

82. Noreen Buckley, What can I do, p. 2.

83. Anne Borsay (2004), 'Personal Trouble or Public Issue? Towards a Model of Policy for People with Physical and Mental Disabilities' Disability \& Society 1 (1986), pp. 179-96. 84. Department of Health, The Problem of the Mentally Handicapped (Dublin, 1960).

85. Diarmaid Ferriter, 'De Valera's Ireland, 1932-58' in Alvin Jackson (ed.) The Oxford Handbook of Modern Irish History (Oxford, 2014), p. 683; Adrian Kelly, 'Catholic Action and the Development of the Irish Welfare State in the 1930s and 1940s' Archivium Hibernicum (53) January 1999, p. 108.

86. Anne Dempsey, People like us: Disability, the people and the facts (Dublin, 1982), p. 41.

87. Mary Daly (2016), Sixties Ireland, p. 10.

88. Despo Kritsotaki (2016), 'Turning', pp. 982-3.

89. Disability Federation of Ireland, 'DFI welcomes historic UN CRPD ratification' March 2018 (Dublin) (https://www.disability-federation.ie/news/press-releases/2018/03/07/ dfi-welcomes-historic-un-crpd-ratification/)

\section{BIBLIOGRAPHY}

Abbott, Pamela, and Roger Sapsford. Community Care for Mentally Handicapped Children. Milton Keynes: Open University Press, 1988.

Akenson, Donald. A Mirror to Kathleen's Face: Education in Independent Ireland 1922-60. Abingdon: Routledge, 2012.

. The Irish Education Experiment: The National System of Education in the Nineteenth Century. Abingdon: Routledge, 2012b.

Bang, Henrik P. "Among everyday makers and expert citizens." In Remaking Governance, edited byJanet Newman, 159-79. Bristol: Policy Press, 2005.

Barrington, Ruth. Health, medicine \& politics in Ireland, 1900-1970. Dublin: Institute of Public Administration, 1987.

Borsay, Anne. Disability and Social Policy in Britain since 1750: A History of Exclusion. Hampshire: Palgrave, 2004.

Bourdieu, Pierre. "The Forms of Capital." In Handbook of Theory and Research for the Sociology of Education, edited byJohnG Richardson, 234-44. Westport: Greenwood Publishing, 1986.

Buck, Pearl S. The Child Who Never Grew: A Memoir. New York: Open Road Media, 2012, 1950.

Buckley, Sarah-Anne. The cruelty man: child welfare, the NSPCC and the state in Ireland, 1889-1956. Manchester: Manchester University Press, 2013.

Carey, Allison C. On the margins of citizenship: intellectual disability and civil rights in twentieth century America. Philadelphia: Temple University Press, 2009.

Castle, Katherine. "Nice, average Americans": post-war parents' groups and the defence of the normal family." In Mental Retardation in America: A historical reader, edited bySteven Noll, and James Trent, 351-71. New York: NYU Press, 2004.

Choudhury, Rubahanna Amannah. 'The Forgotten Children: The Association of Parents of Backward Children and the Legacy of Eugenics in Britain, 1946-1960'. PhD Thesis: Oxford Brookes University, 2015.

Clancy, Patrick. "Education in the Republic of Ireland: the project of modernity?" In Irish Society: Sociological Perspectives, edited byPatrick Clancy, 467-95. Dublin: Institute of Public Administration, 1995.

Coolahan, John. Irish Education: Its History and Structure. Dublin: Institute of Public Administration, 1981.

Cooney, John. A Service for the Mentally Handicapped. Dublin, 1963.

Cooter, Roger. "Medicine and Modernity." In The Oxford Handbook of the History of Medicine, edited byMark Jackson, 100-17. Oxford: Oxford University Press, 2011.

Cousins, Mel. "The Irish Social Protection System: Change in a Comparative Perspective'." In The Irish Welfare State in the Twenty-First Century: Challenges and Change, edited byMaryP Murphy, and Fiona Dukelow, 37-66. London: Palgrave Macmillan, 2016.

Daly, Mary. "The primary and natural educator'?: The role of parents in the education of their children in Independent Ireland' Éire-Ireland 44 (1\&2) Spring/Summer." (2009): 194-217. 
Sixties Ireland: Reshaping the Economy, State and Society, 1957-73. Cambridge: Cambridge University Press, 2016.

Dorr, Donal. Option for the Poor: A Hundred Years of Vatican Social Teaching. New York: Orbis Books, 1983.

Earner-Byrne, Lindsey. Mother and child: maternity and child welfare in Dublin, 1922-60. Manchester: Manchester University Press, 2007.

Farber, Bernard. Mental Retardation: Its social context and social consequences. Boston: Houghton Mifflin, 1968.

Finlayson, Geoffrey. "A Moving Frontier: Voluntarism and the State in British Social Welfare 1911-1949." wentieth Century British History, 1st edn ed, 183-206, 1990.

Finnegan, Frances. Do Penance or Perish: Magdalene Asylums in Ireland. Oxford University Press: Oxford, 2004.

Fuller, Louise. Irish Catholicism since 1950: the undoing of a culture. Dublin: Gill and Macmillan, 2004.

Harvey, Brian. Evolution of Health Services and Health Policy in Ireland. Dublin: Combat Poverty Agency, 2007.

Healy, Sean, and Brigid Reynolds. Social Policy in Ireland: Principles, Practice and Problems. Dublin: Liffey Press, 2006.

Hilton, Matthew, James McKay, Nicholas Crowson, and Jean-François Mouhot. "The Big Society: Civic Participation and the state in Modern Britain History and Policy." (2010).

Hilton, Matthew., Nick Crowson., Jean-François Mouhot, and James McKay. A historical guide to NGOs in Britain: Charities, Civil Society and the Voluntary Sector since 1945. Hampshire: Palgrave, 2012.

., James McKay, and Jean-François Mouhot. The Politics of Expertise: How NGOs Shaped Modern Britain. Oxford University Press: Oxford, 2013.

Holohan, Carole. "Conceptualizing and responding to poverty in the Republic of Ireland in the 1960s: a case study of Dublin-41." Social History, 34-53, 2016.

Inglis, Tom. Moral monopoly: the rise and fall of the Catholic Church in modern Ireland. Dublin: University College Dubl, 1998.

Jackson, Mark. "Grown-Up Children': Understandings of Health and Mental Deficiency in Edwardian England." In Cultures of Child Health in Britain and the Netherlands in the Twentieth Century, edited byMarijke Giijswijt-Hofstra, and Hilary Marland, 149-68. Amsterdam: Editions Rodopi, 2003.

Jones, Kathleen W. "Education for children with mental retardation: Parent Activism, Public Policy and Family Ideology in the 1950s." In Mental Retardation in America: A historical reader, edited bySteven Noll, and James Trent, 322-51. New York: NYU Press, 2004.

Kavanagh, James. Manual of Social Ethics. Dublin: M.H. Gill, 1956.

Kritsotaki, Despo. "Turning private concerns into public issues: mental retardation and the parents' movement in post-war Greece, C. 1950-80." Journal of Social History 49, no. 4 (2016), no. : 982-98.

Lee, Joseph. Ireland, 1912-1985: Politics and Society. Cambridge: Cambridge University Press, 1989.

Lennard Davis. ed. The Disability Studies Reader, 2nd edn. New York: Taylor and Francis, 1997

Lewis, lan. Making a difference: sixty years of service to the people of South Australia, 1950-2010. Netley, 2010.
McManus, Antonia. The Irish Hedge School and Its Books, 1695-1831. Dublin: Four Courts Press, 2004.

Meehan, Ciara. A Just Society for Ireland? 1964-1987. Hampshire: Palgrave, 2013.

Murray, Peter, and Maria Feeny. Church, State and Social Science in Ireland: Knowledge Institutions and the Rebalancing of Power 1937-73. Oxford: Oxford University Press, 2016.

Murray, Thomas. Contesting Economic and Social Rights in Ireland: Constitution, State and Society, 1848-2016. Cambridge: Cambridge University Press, 2016.

Nielsen, Kim. E. A Disability History of the United States. Boston: Beacon Press, 2012.

O'Sullivan, Eoin. Suffer the Little Children: The inside story of Ireland's Industrial Schools. Dublin: New Island Books, 1999.

Pelka, Fred. What We Have Done: An Oral History of the Disability Rights Movement. Amherst: University of Massachusetts Press, 2012.

Perkin, Harold. The Rise of Professional Society: England Since 1880. Abingdon: Routledge, 2003.

Pickstone, John. "Medicine, society and the state." In The Cambridge Illustrated History of Medicine, edited byRoy Porter, 304-42. Cambridge: Cambridge University Press, 2001.

Pollard, John. The Papacy in the age of totalitarianism 1914-58. Oxford University Press: Oxford, 2016.

- Landscapes of Care: Comparative Perspectives on Family Caregiving. Abingdon: Routledge, 2010.

Power, Andrew., Janet E. Lord, and Allison DeFranco. Active Citizenship and Disability: Implementing the Personalisation of Support. Cambridge: Cambridge University Press, 2013.

Rolph, Sheena. Reclaiming the past: the role of local MENCAP societies in the development of community care in East Anglia, 1946-80. Milton Keynes: Open University Press, 2002.

Ryan, Annie. Walls of Silence: Ireland's policy towards people with an intellectual disability. Kilkenny: Red Lion, 1999.

Stainton, Tim. 'Equal Citizens? The discourse of liberty and rights in the history of learning disabilities' in Lindsay Brigham \& Dorothy Atkinson (et al.) Crossing Boundaries: Change and Continuity in the History of Learning Disability, 87-101. Kidderminster: BILD Publishing, 2000.

Trent, James. Inventing the Feeble Mind: A history of Mental Retardation in the United States. Berkeley: University of California Press, 1994.

United Nations. "Declaration on the Rights of Mentally Retarded Persons' (1971)." Rights of the Mentally Disabled: Statements and Standards, 8. Washington: American Psychiatric Association, 1984.

Weller, Vicki. An extraordinary voluntary commitment: 25 years of KARE. Kildare: KARE Publishing, 1992.

Whyte, John Henry. Church and State in Modern Ireland: 1923-1979. Dublin: Gill and Macmillan, 1980

Wren, Maev-Ann. Unhealthy State: Anatomy of a sick society. Dublin: New Island Books, 2002

Wright, David. Downs: The history of a disability. Oxford University Press: Oxford, 2011. 